\title{
Genetic and phenotypic diversity of Magnaporthe oryzae from leaves and panicles of rice in commercial fields in the State of Goiás, Brazil
}

\author{
Gisele Barata Silva ${ }^{1}$, Anne S. Prabhu², Marta C.C. Filippi², Maria G. Trindade ${ }^{3}$, Leila G. Araújo ${ }^{3}$ \& Laércio \\ Zambolim $^{1}$
}

${ }^{1}$ Departamento de Fitopatologia, Universidade Federal de Viçosa, 36570-000, Viçosa, MG, Brazil; ${ }^{2}$ Embrapa Arroz e Feijão, 75375-000, Santo Antônio de Goiás, GO, Brazil; ${ }^{3}$ Laboratório Nacional Agropecuário - LANAGRO, Ministério da Agricultura, Pecuária e Abastecimento, 74674-025, Goiânia, GO, Brazil

Author for correspondence: Gisele B. Silva, e-mail: gisele.barata@ufra.edu.br

\begin{abstract}
Genetic and phenotypic structure of Magnaporthe oryzae populations of two upland rice cultivars was determined. Monoconidial isolates were obtained from rice blast affected fields, four from cv. BRS Bonança and four from cv. Primavera, in Goias State (20012003). The pathotypes IB-41 and IB-9 were predominant in both leaf and panicle isolates of BRS Bonança and IF-1 in Primavera. A great majority of pathotypes were common to both leaf and panicle subpopulations of Bonança (42.8\%) and Primavera (66.6\%). The ANOVA of virulence data showed high variability within population of each cultivar. There was no significant difference in virulence pattern of isolates from leaves and panicles, independent of collection site and cultivar. The molecular characterization of isolates was done employing the rep-PCR analysis with two primer sequences from Pot2. The genetic analysis of 538 isolates showed a high genotypic diversity in both leaf and panicle pathogen populations with 103 haplotypes in Bonança and 49 in Primavera. The migration of pathotypes from leaves to panicles in each field was $70.8 \%$ and $36.6 \%$ for Primavera and BRS Bonança, respectively. The diversity of $M$. oryzae population was influenced by cultivar of origin. A great amount of population diversity was encountered within the same field.
\end{abstract}

Keywords: Pyricularia grisea, virulence, Rep-PCR, rice blast.

\section{RESUMO}

Diversidade genética e fenotípica de Magnaporthe oruzae de folhas e panículas de arroz no Estado de Goiás, Brasil

A estrutura genética e fenotípica da população de Magnaporthe oryzae foi estudada em folhas e panículas de duas cultivares de arroz de terras altas. Os isolados monospóricos foram obtidos em lavouras comerciais de arroz, quatro da cv. BRS Bonança e quatro da cv. Primavera, Goiás-Brasil (2001-2003). As raças IB-41 e IB-9 foram as predominantes entre os isolados de folhas e panículas de Bonança e a raça IF-1 para Primavera. De 35 e 27 raças identificadas de Bonança (42,8\%) e Primavera (66,6\%) foram comum a ambas as subpopulações de folha e panículas. Um total de 15 raças não encontradas em folhas foi detectado em baixa freqüência em panícula de Bonança. A anova da virulência, mostrou elevada variabilidade dentro de subpopulação de cada cultivar. Não existiu mudança significativa no padrão de virulência dos isolados de folhas e panículas, independente do local e cultivar. A caracterização molecular dos isolados foi realizada por Rep-PCR com dois primers da seqüência Pot 2. A análise genética dos 538 isolados mostrou elevada diversidade genotípica nas populações de folha e de panículas, com 103 perfis em Bonança e 49 em Primavera. A migração de raças de folhas para panículas em cada lavoura foi de 70,8\% (Primavera) e 36,5\% (Bonança). A maior parte da diversidade da população foi encontrada dentro de cada lavoura.

Palavras chave: Pyricularia grisea, virulência, Rep-PCR, brusone.

\section{INTRODUCION}

Rice blast caused by Magnaporthe oryzae (T.T. Hebert) M.E. Barr (anamorph Pyricularia oryzae Sacc.) is economically the most important disease of upland rice.

\footnotetext{
Part of the Thesis of the first author. Universidade Federal de Viçosa. Viçosa MG. 2004.

*Present Address: Laboratório de Microbiologia Agrícola, ICA, Universidade Federal Rural da Amazônia, 66077-530, Belém, PA, Brazil
}

The critical phases for disease epidemics occur within 25 to 35 days after planting and during milk and dough stages of grain filling. The Magnaporthe-rice pathosystem has been divided into two sub-pathosystems, leaf blast and panicle blast for epidemiological studies (Teng, 1994).

Leaf blast and panicle blast cause grain yield losses indirectly and directly, respectively. The widely grown rice cultivars Primavera and BRS Bonança in the Brazilian state of Goias are susceptible to blast. The susceptibility of rice cv. Primavera has increased since its release in 1996 and, according to Araújo et al. (2004), panicle blast was 
responsible for $42.7 \%$ of empty spikelets in cv. Primavera and $11 \%$ in $\mathrm{cv}$. BRS Bonança.

Different breeding strategies are being adopted to increase the durability of resistance in different rice-growing countries, and these require knowledge on the population structure of the pathogen. The population structure is considered to be the amount of genetic and phenotypic variation and can vary through time and space as these populations evolve or adapt in response to environmental conditions (McDonald \& Linde, 2002).

The fungus $M$. oryzae is considered highly variable and is composed of a large number of physiological races or pathotypes. The race of an isolate is determined based on the reaction pattern in a set of eight cultivars referred to as standard international differentials (Ling \& Ou, 1969). In Brazil, the pathogenic diversity of 85 isolates of $M$. oryzae collected from 14 upland rice cultivars in experimental plots, during a period of five years, was analyzed (Prabhu et al., 2002). Eleven international races were identified, the predominant being IB-9 (56.4\%), IB-1 (16.4\%) and IB-41 $(11.8 \%)$.

The information on pathogenicity of $M$. oryzae based on the pathotype identification is restricted only to the reactions of cultivars used as international differentials. Thus, the analysis of virulence using agriculturally important local cultivars other than the international differentials has great value for the utilization of genes that exhibit a wide spectrum of resistance to a determined population (Bonman et al., 2002). Analysis of the population structure of $M$. oryzae using genetic markers in addition to virulence spectrum adds information on several aspects of evolutionary dynamics under field conditions (Kang \& Lee, 2000).

Population structures of $M$. oryzae from ricegrowing regions in different countries with MGR-586 and other molecular markers have shown that these populations can be organized into genetically distinct lineages or groups (Chen et al., 1995, Zeigler et al., 1997, Kumar et al., 1999). In Korea, the genetic analysis of 176 isolates of M. oryzae collected in farmers' fields and nurseries did not show a well defined lineage structure (Park et al., 2003). Rathour et al. (2004), in the northwestern Himalyan region of India, also showed the presence of high genetic diversity and continuous variation in 48 isolates, using RAPD markers. These studies were mostly based on isolates collected from sporulating leaf lesions.

The majority of studies on population structure of $M$. oryzae conducted from isolates collected in experiments which contain diverse genotypes or in small production areas in the Himalayas showed wide diversity, resulting in a great number of lineages. The collection of isolates from largescale farmers' rice fields provides a less biased assessment of the actual composition of the pathogen population in a given cultivar.

In breeding for blast resistance the selection of plants is mostly made based on observations on leaf blast, while the infection of greatest economic importance occurs on the panicle (Bonman et al., 1992). Previous studies on the relation between leaf and panicle blast were conflicting and were attributed to differences in the degree of disease resistance of leaf and panicle, climatic factors and differences in race frequency in the leaf and panicle blast stages. Some investigators (Bonman et al., 1989) have shown significant correlations between leaf and panicle blast incidence and/or severity, whereas others have reported distinct differences (Ra et al., 1995). However, the relative level of resistance to leaf blast and neck blast varies in certain rice cultivars (Bonman et al., 1992). In Korea, based on the experiments conducted with two cultivars planted in adjoining plots, it was demonstrated that $30 \%$ to $50 \%$ of races of M. oryzae present during the vegetative phase incite disease in panicles in the same field (Han et al., 1997). Knowledge is limited on the population structure at critical stages in blast disease epidemics on leaf and panicles, in isolated commercial fields of a cultivar. The differences in leaf and panicle blast epidemics and the capacity of the pathogen to migrate from leaf to panicle raises important questions about the population dynamics of $M$. oryzae. The objective of the present investigation was to study the genetic and phenotypic structure, both among and within the populations from leaves and panicles of two upland rice cultivars, in Brazilian commercial rice fields.

\section{MATERIALS AND METHODS}

\section{Isolates}

Leaf and panicle blast samples were collected from eight commercial fields of upland rice cultivars, four cultivated with cv. BRS Bonança and four cv. Primavera, in five municipalities in the State of Goias, Brazil, during two consecutive rice growing seasons. The selected rice fields were isolated and separated from each other at a minimum distance of $50 \mathrm{~km}$, except one field of cv. BRS Bonança (Field no.2) which was only $200 \mathrm{~m}$ away from $\mathrm{cv}$. Primavera. Regular surveys of the fields were made for the collection of isolates of M. oryzae from leaf and panicles. Samples from sporulating lesions on leaves were collected, 30 to 50 days after planting, during the vegetative phase, whereas samples were obtained from the panicles, 80 to 90 days after planting, during the grain filling stage. The fields are of varying sizes, ranging from 5 to 100 hectares, and in each field a representative area of one hectare was selected for sampling. Five different sites in the selected area (1ha), four in the extremities of a quadrate and one in the center, separated by $100 \mathrm{~m}$, were marked with long wooden sticks. Fifty leaves with sporulating blast lesions and 100 infected panicles were sampled at each of the five sites per field. Monoconidial isolates were obtained by directly transferring one conidium per lesion on 5\% water agar from two to three lesions per leaf. The isolates from panicles in the majority of the cases were obtained from one conidium per panicle. The collection, composed of 2082 isolates, 
was conserved on sterilized filter paper discs in a freezer at $-20^{\circ} \mathrm{C} \pm 1^{\circ} \mathrm{C}$. The total number of isolates collected from leaves and panicles according to cultivar, location and year are presented in Table 1.

\section{Genotypes}

Thirty-two genotypes were used, including eight international differentials (Dular, Kanto 51, NP-125, Raminad Str 3, Usen, Zenith, Caloro and Sha-tiao-tsao), eight Brazilian differentials (Carajás, Confiança, Maravilha, Primavera, Progresso, Caiapó, IAC-47, IAC-201) (Prabhu et al., 2002), the cultivars BRS Bonança and IAC-25, six near isogenic lines of rice cultivar IAC-25 (CNA-2006, CNA-8198, CNA-8199, CNA-8210, CNA-8212, CNA8209), and eight Japanese differential cultivars (Shin-2, Aichi- Asahi, Ishikarishiroke, Tsuyuake, Fukunishiki, Yashiro Mochi, Pi-4, Toride-1). These genotypes were sown in plastic trays $(30 \times 15 \times 10 \mathrm{~cm})$ containing $3 \mathrm{~kg}$ of soil fertilized with NPK (5g of 5-30-15 $+\mathrm{Zn}$ and $3 \mathrm{~g}$ of ammonium sulfate). An additional $2 \mathrm{~g}$ of ammonium sulfate was applied 18 days after planting. Ten to twelve seeds of each entry were sown in 4-cm-long rows totaling 16 rows per tray, eight on either side of the tray.

\section{Inoculation and evaluation}

Mycelial growth, sporulation on culture medium and inoculation procedure were as described in earlier investigations (Filippi \& Prabhu, 2001). Inoculations were made at fortnightly intervals with 50 individual isolates on 21 -day-old plants with conidial suspension $\left(3.10^{5}\right.$ conidia. $\mathrm{mL}^{-1}$ ) using atomizer. A tray containing international and Brazilian differentials sprayed with water was maintained as a non-inoculated control to ensure that no contamination occurred during the inoculation procedure. The inoculations were repeated when the non-inoculated controls were infected as well as when the cultivars of origin were not infected. Leaf blast reaction was assessed seven to nine days after inoculation, taking into consideration only two types of reaction of the host, compatible or susceptible and incompatible or resistant reaction.
The lesion types $0,1,2$, and 3 were considered as resistant and 4 to 9 as susceptible (IRRI, 1988). The physiologic races were identified based on the reaction on eight international differentials (Filippi \& Prabhu, 2001).

\section{DNA extraction and amplification}

DNA extraction was performed utilizing the CTAB method modified by Doyle \& Doyle (1987). The quality of DNA was verified in gel agarose $(1 \%)$ and the concentration was estimated by fluorometer and adjusted to $10 \mathrm{ng} / \mu \mathrm{L}$. The molecular characterization of isolates of M. oryzae was performed by rep-PCR, with two primer sequences of the repetitive element Pot 2 (Pot2-1 and Pot2-2) according to the protocol described by George et al. (1998). The DNA products were separated by gel electrophoresis on agarose $(0.5 \%)+$ synergel $(0.75 \%)$. After applying $25 \mu \mathrm{L}$ of reaction and 5 $\mu \mathrm{L}$ of bromophenol blue stain, the gels were treated with ethidium bromide. The gels were later photographed under ultra-violet light, utilizing the photo documentation system, Eagle Eye II (Stratagene).

\section{Data analysis}

The frequency of predominant races, identified based on international differentials, was calculated for each rice field for isolates collected from leaves as well as from panicles. The number of haplotypes and genetic and phenotypic diversity was determined based on Nei's index (Nei, 1987).

$$
\hat{H}=\frac{n}{n-1}\left(1-\sum_{i=1}^{k} p_{i}^{2}\right)
$$

Where $n$ is the number of gene copies in the sample, $k$ is the number of haplotypes, and $p_{1}$ is the sample frequency of the $i$ th haplotype (Nei, 1987) A binary matrix indicating compatible reaction (1) and incompatible reaction (0) of each isolate was utilized for constructing a matrix of similarity between all pairs of isolates according to the coefficient of Jaccard. Cluster analysis was conducted and phenograms were generated based on similarity coefficients using

TABLE 1 - Number of monosporic isolates of Magnaporthe oryzae established according to field, location, year and phenological stage on upland rice cultivars BRS Bonança and Primavera

\begin{tabular}{lllrrr}
\hline \hline \multirow{2}{*}{ Field } & \multirow{2}{*}{ Identification } & \multirow{2}{*}{ Location } & \multirow{2}{*}{ Year } & \multicolumn{2}{c}{$\mathbf{N}^{\mathbf{0}}$ of isolates } \\
\cline { 5 - 6 } & & & & Leaf & Panicle \\
\hline Bonança & B1 & Piracanjuba & 2002 & 256 & 84 \\
Bonança & B2 & Piracanjuba & 2002 & 147 & 125 \\
Bonança & B3 & Bela Vista & 2003 & 110 & 80 \\
Bonança & B4 & Uruana & 2003 & 53 & 70 \\
\hline Primavera & P1 & Santo Antônio de Goiás & 2002 & 311 & 212 \\
Primavera & P2 & Santo Antônio de Goiás & 2002 & 220 & 195 \\
Primavera & P3 & Bela Vista & 2003 & 100 & 90 \\
Primavera & P4 & Ceres & 2003 & 80 & 95 \\
\hline Total & - & & 2 & 1.167 & 915 \\
\hline
\end{tabular}


unweighted pair group method with arithmetic averages (UPGMA) using the SAHN program of the NTSYS pc package. Isolates with distinct DNA fingerprints were considered haplotypes. The phenogram with the best fit to the similarity matrix was based on co-phenetic values $(\mathrm{COPH})$.

The statistical divergences were estimated by hierarchical analysis of variance based on the phenotypic and genetic binary data (AMOVA) (Excoffier et al., 1992). The population was defined by cultivars and subpopulations by phenological stages. The total variance was divided in three levels for analyzing the percentage of existing variation between groups (Bonança x Primavera and Leaf $x$ Panicle), among populations within the group and within the populations, using the Arlequin program version 2001.

\section{RESULTS}

\section{Phenotypic diversity}

The pathotypes IB-41 and IB-9 were predominant in both leaf and panicle isolates of cv. BRS Bonança, whereas in populations of $\mathrm{cv}$. Primavera IF-1 was found to be the most frequent pathotype (Figure 1). Of the 35 pathotypes identified among isolates retrieved from cv. BRS Bonança, 15 were common in both leaf and panicle subpopulations, corresponding to $42.8 \%$. On the other hand, of the 27 pathotypes, 18 were encountered in both leaf and panicle populations of $\mathrm{cv}$. Primavera, corresponding to $66.6 \%$. Fifteen pathotypes among panicle isolates of BRS Bonança, and two from Primavera, were found in low frequency, but they were not present in leaf isolates. Nei's indexes of virulence pattern on 32 genotypes in different fields of both leaf and panicle subpopulations were higher than 0.9 , indicating high phenotypic diversity of $M$. oryzae within each field (Table 2).

The analysis of variance of virulence data of $M$. oryzae isolates showed that the variation within each field was high for leaf $(54.24 \%)$ as well as for panicle isolates $(68.05 \%)$. Only a small part of the total variation between fields within cultivar occurred for leaf $(9.13 \%)$ and panicle isolates $(12.88 \%)$, indicating that the phenotypic virulence pattern in each phenological stage between the populations of the same cultivar is similar independent of field (Table $3)$. The differences between cultivars were significant for leaf $(36.62 \%)$ as well as for panicle isolates $(19.07 \%)$.

Considering the population by cultivar, the phenotypic variability of isolates of cv. BRS Bonança and cv. Primavera were $80.88 \%$ and $90.19 \%$, respectively, in each field, indicating that a great part of the total variation among isolates collected from leaves and panicles is present within the population (Table 3 ). The phenotypic variation among isolates within leaf and panicles of cv. BRS Bonança (18.40\%) was greater than in the populations of $\mathrm{cv}$. Primavera $(9.47 \%)$. The virulence pattern of isolates in the vegetative phase on leaves was similar to that of panicle in each cultivar. The variation was only $0.72 \%$ and $0.37 \%$ between subpopulation of leaf and panicles of cvs. BRS Bonança and Primavera, respectively.

\section{Genetic diversity}

The rep-PCR banding pattern of $80 \mathrm{M}$. oryzae isolates obtained with the primer Pot 2 is shown in Figure 2. The number of bands ranged from 9 to 17 , of which 8 to 6 were polymorphic. There was no difference in banding pattern between isolates from leaves and panicles. The molecular
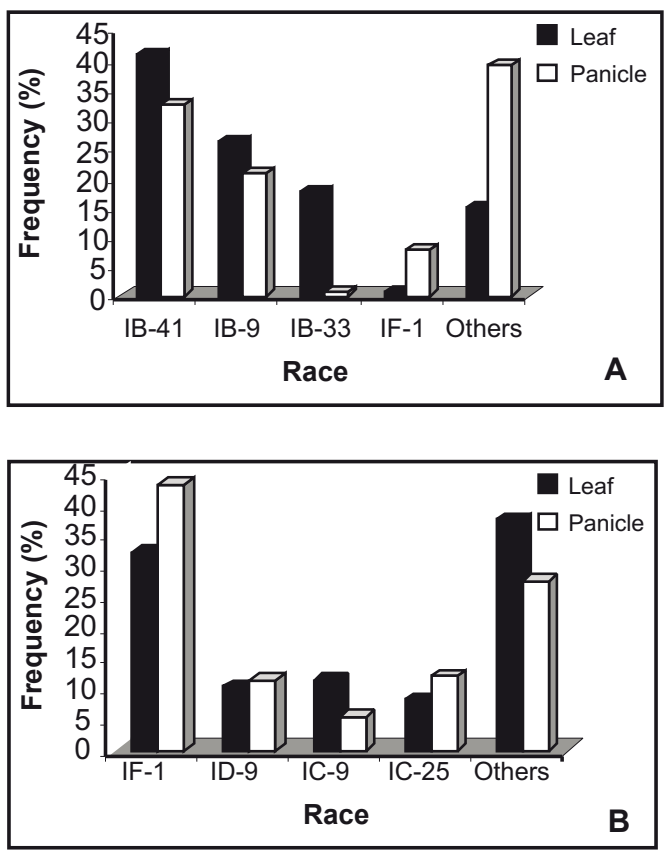

80
FIGURE 1 - Frequency distribution of pathotypes of Magnaporthe oryzae among isolates collected from leaves and panicles in naturally infected farmers' fields of cultivars BRS Bonança A. and Primavera B. The pathotypes were identified based on the reaction pattern on eight standard international differentials under controlled greenhouse conditions. 
analysis of 267 of M. oryzae isolates from cv. BRS Bonança and 271 from cv. Primavera was performed based on the occurrence and distribution of five to 13 fragments of DNA obtained by rep-PCR. The amplified DNA of the isolates of cv. BRS Bonança and cv. Primavera generated bands with molecular weights varying between 0.7 and $16 \mathrm{~Kb}$ (Figure 2 ). The phenogram constructed from fingerprint data from 80 randomly selected isolates showed two main groups considering 50\% similarity level, one constituted of only isolates from cv. Primavera and the other with the isolates from cv. BRS Bonança with a co-phenetic correlation coefficient of 0.74 (Figure 3).

Considering the analysis using Nei's index, high genotypic diversity was detected in pathogen population of cv. BRS Bonança, with one exception of leaf population in field B4 (Table 4). All others were higher than 0.9, indicating that each isolate of $M$. oryzae exhibits a unique pattern. On the other hand, the M. oryzae population of cv. Primavera showed low genotypic diversity in the sub-population of leaf isolates, varying from 0.089 to 0.476 , with the exception of field P3 where the index was 0.868 (Table 5). However, a high diversity was detected in the sub-population from panicles, the index being more than 0.9 in all four fields. There was no association between virulence and rep-PCR patterns of isolates.

The isolates from leaf and panicle did not show any defined cluster. The distribution of genetic diversity among and within populations analyzed on the basis of AMOVA showed that a major part of the diversity was distributed within each field, independent of cultivar (Table 4). The analysis further revealed significant differences in diversity between cultivars $(39.44 \%)$ for isolates from leaves, but the variation was reduced to $10.07 \%$ for panicle isolates. The diversity within fields was higher for panicle isolates $(64.92 \%)$ than for leaf isolates $(36.22 \%)$.

Considering the isolates of BRS Bonança, the hierarchical genetic diversity analysis indicated that $70.38 \%$ of total diversity was distributed within fields of both leaf and panicle isolates, whereas the rate was $32.36 \%$ among isolates within each subpopulation of leaf and panicle (Table 4). The difference between subpopulations of leaf and panicle was non-significant (-2.75\%). The within field diversity of $M$. oryzae population from cv. Primavera was $50.73 \%$, and within leaf and panicle isolates was $30.12 \%$. The diversity between leaf and panicle blast subpopulations of cv. Primavera was significant (19.15\%), indicating that the molecular pattern of isolates from leaves as well as panicles of the same cultivar is similar independent of location of the field from which the isolates were collected.

\section{DISCUSSION}

The phenotypic and genetic structure of $M$. oryzae isolates from leaf and panicles was examined by conventional pathotype analysis and virulence pattern on 32 genotypes and by DNA fingerprinting using rep- PCR.
The frequency of predominant pathotypes within leaf and panicle isolates was similar within the same farm. Pathotypes IB-9 and IB-41 were common among both leaf and panicle isolates collected from cv. BRS Bonança. These pathotypes were also found to be predominant in an earlier study with 72 isolates of $M$. oryzae collected in experimental fields of 10 upland rice cultivars during 1994-1997 (Filippi \& Prabhu et al., 2001), indicating their high frequency and preexistence in upland rice cultivars. On the other hand, the predominant pathotype IF-1 among both leaf and panicle isolates of Primavera was not reported in earlier studies probably because of the small sample of isolates used in the analysis (Prabhu et al., 2003). In the present study, the $M$. oryzae population analysis of $\mathrm{cv}$. Primavera also showed high cultivar specificity of pathotype, independent of collection site.

Of the pathotypes identified among isolates retrieved from cvs. Bonança and Primavera, $42.8 \%$ and $66.6 \%$ occurred both in the leaf and panicle, respectively. These results are in agreement with those obtained by Han et al. (1997) in Korea. According to these authors, approximately 30 to $50 \%$ of isolates from panicle blast stage possibly migrated from leaf to panicle in the same field in two irrigated rice cultivars. The migration of pathotypes within the same field from one phenological stage to the other is considered as a common phenomenon within $M$. oryzae-rice pathosystems (Chen et al., 1995). The observed low frequency of 15 rare pathotypes among panicle isolates of $\mathrm{cv}$. Bonança which were not present in the leaf may have occurred due to change in the pathotype pattern at adult plant stage before heading.

While the pathotype analysis provides limited information on phenotypic diversity of populations, the virulence pattern on 32 selected genotypes provides a more useful basis for characterizing the $M$. oryzae population structure of leaf and panicle blast. The virulence pattern of isolates in the vegetative phase on leaves was similar to that on the panicle in each cultivar, confirming the results of the pathotype assay. More of the variation was concentrated within the field than between fields of a given cultivar.

In Korea the irrigated rice cultivars Jinmibyeo and Nagdonghyen were grown in adjoining plots (Han et al., 1997). In the present study the fields of upland rice cultivars Bonança and Primavera were isolated and distant from one another. There was a high degree of similarity in population structure among fields within the cultivar. Despite the distance, a small part of the total variation between fields within cultivar occurred for leaf $(9.13 \%)$ and panicle $(12.88 \%)$ isolates. Although alloinfection, which is common in the experimental plots, was reduced, long-distance spore travel cannot be eliminated. According to McDonald et al. (1999), a high degree of similarity among populations collected from widely separated geographic regions suggests the occurrence of long-distance dispersal and gene flow. 
TABLE 2 - Phenotypic diversity of Maganporthe oryzae population obtained by analysis of variance

\begin{tabular}{cccccc}
\hline \hline Field & $\begin{array}{c}\text { Number of } \\
\text { isolates }\end{array}$ & $\begin{array}{c}\text { Number of } \\
\text { haplotypes }\end{array}$ & $\begin{array}{c}\text { Number of } \\
\text { polymorphic loci }\end{array}$ & $\begin{array}{c}\text { Genotypic } \\
\text { diversity }\end{array}$ & $\begin{array}{c}\text { Standard } \\
\text { deviation (+/-) }\end{array}$ \\
\hline BF1 & 48 & 47 & 24 & 0.999 & 0.005 \\
BF2 & 49 & 48 & 24 & 1.000 & 0.004 \\
BF3 & 48 & 43 & 24 & 0.993 & 0.007 \\
BF4 & 38 & 36 & 30 & 0.996 & 0.008 \\
BP1 & 50 & 50 & 28 & 1.000 & 0.004 \\
BP2 & 44 & 44 & 25 & 1.000 & 0.005 \\
BP3 & 47 & 45 & 28 & 0.997 & 0.006 \\
BP4 & 39 & 38 & 27 & 0.999 & 0.019 \\
PF1 & 48 & 28 & 23 & 0.949 & 0.019 \\
PF2 & 46 & 33 & 21 & 0.961 & 0.019 \\
PF3 & 45 & 42 & 25 & 0.996 & 0.006 \\
PF4 & 44 & 38 & 22 & 0.978 & 0.016 \\
PP1 & 44 & 38 & 21 & 0.993 & 0.007 \\
PP2 & 38 & 31 & 19 & 0.989 & 0.009 \\
PP3 & 42 & 40 & 27 & 0.999 & 0.007 \\
PP4 & 42 & 39 & 25 & 0.998 & 0.006 \\
\hline
\end{tabular}

TABLE 3 - Hierarchical distribution of phenotypic virulence among Magnaporthe oryzae populations (phenological stage and cultivar) from rice cultivars BRS Bonança and Primavera

\begin{tabular}{|c|c|c|c|c|c|c|c|c|c|}
\hline \multirow[b]{3}{*}{ Populations } & \multicolumn{4}{|c|}{ Phenological state ${ }^{x}$} & \multicolumn{5}{|c|}{ Cultivars ${ }^{\mathrm{y}}$} \\
\hline & \multicolumn{4}{|c|}{ Percentage of total variation $^{z}$} & \multicolumn{5}{|c|}{ Percentage of total variation ${ }^{z}$} \\
\hline & $\begin{array}{l}\text { Sample } \\
\text { size }\end{array}$ & $\begin{array}{l}\text { Between } \\
\text { cultivars }\end{array}$ & $\begin{array}{c}\text { Between } \\
\text { fields } \\
\text { within } \\
\text { cultivar }\end{array}$ & $\begin{array}{l}\text { Within } \\
\text { cultivars }\end{array}$ & Populations & $\begin{array}{l}\text { Sample } \\
\text { size }\end{array}$ & $\begin{array}{c}\text { Between } \\
\text { leaf and } \\
\text { panicle }\end{array}$ & $\begin{array}{c}\text { Among isolates } \\
\text { within leaf and panicle }\end{array}$ & $\begin{array}{l}\text { Within } \\
\text { the } \\
\text { field }\end{array}$ \\
\hline Leaf & 366 & 36.62 & 9.13 & 54.24 & Bonança & 363 & 0.72 & 18.40 & 80.88 \\
\hline Panicle & 346 & 19.07 & 12.88 & 68.05 & Primavera & 349 & 0.37 & 9.47 & 90.19 \\
\hline
\end{tabular}

${ }^{\times}$Magnaporthe grisea populations considering leaf and panicle.

${ }^{\mathrm{y}}$ Magnaporthe grisea populations considering cultivar Primavera and Bonança.

${ }^{\mathrm{z}}$ Based on analysis of variance obtained from phenotypic virulence data.

${ }^{1}$ Probability $(\mathrm{P})$ of obtaining an estimate of component greater than the observed values.

TABLE 4 - Hierarchical distribution of gene diversity among Magnaporthe oryzae populations (phenological stage and cultivar) from rice cultivars BRS Bonança and Primavera

\begin{tabular}{|c|c|c|c|c|c|c|c|c|c|}
\hline \multirow[b]{3}{*}{ Populations } & \multirow{2}{*}{\multicolumn{4}{|c|}{$\begin{array}{l}\text { Phenological state }^{\mathrm{x}} \\
\text { Percentage of total variation }^{z}\end{array}$}} & \multicolumn{5}{|c|}{ Cultivars $^{\mathrm{z}}$} \\
\hline & & & & & & Per & entage of $t$ & tal variation $^{z}$ & \\
\hline & $\begin{array}{c}\text { Sample } \\
\text { size }\end{array}$ & $\begin{array}{l}\text { Between } \\
\text { cultivars }\end{array}$ & $\begin{array}{c}\text { Between } \\
\text { fields } \\
\text { within } \\
\text { cultivar }\end{array}$ & $\begin{array}{l}\text { Within } \\
\text { cultivars }\end{array}$ & Populations & $\begin{array}{l}\text { Sample } \\
\text { size }\end{array}$ & $\begin{array}{c}\text { Between } \\
\text { leaf and } \\
\text { panicle }\end{array}$ & $\begin{array}{c}\text { Among isolates } \\
\text { within leaf and panicle }\end{array}$ & $\begin{array}{c}\text { Within } \\
\text { the } \\
\text { field }\end{array}$ \\
\hline Leaf & 299 & 39.44 & 24.34 & 36.22 & Bonança & 267 & -2.75 & 32.36 & 70.38 \\
\hline Panicle & 239 & 10.27 & 25.00 & 64.92 & Primavera & 271 & 19.15 & 30.12 & 50.73 \\
\hline
\end{tabular}

${ }^{\times}$Magnaporthe grisea populations considering leaf and panicle.

${ }^{\mathrm{y}}$ Magnaporthe grisea populations considering cultivar Primavera and Bonança.

${ }^{\mathrm{z}}$ Based on analysis of molecular variance obtained from molecular data.

${ }^{1}$ Probability $(\mathrm{P})$ of obtaining an estimate of component greater than the observed values. 


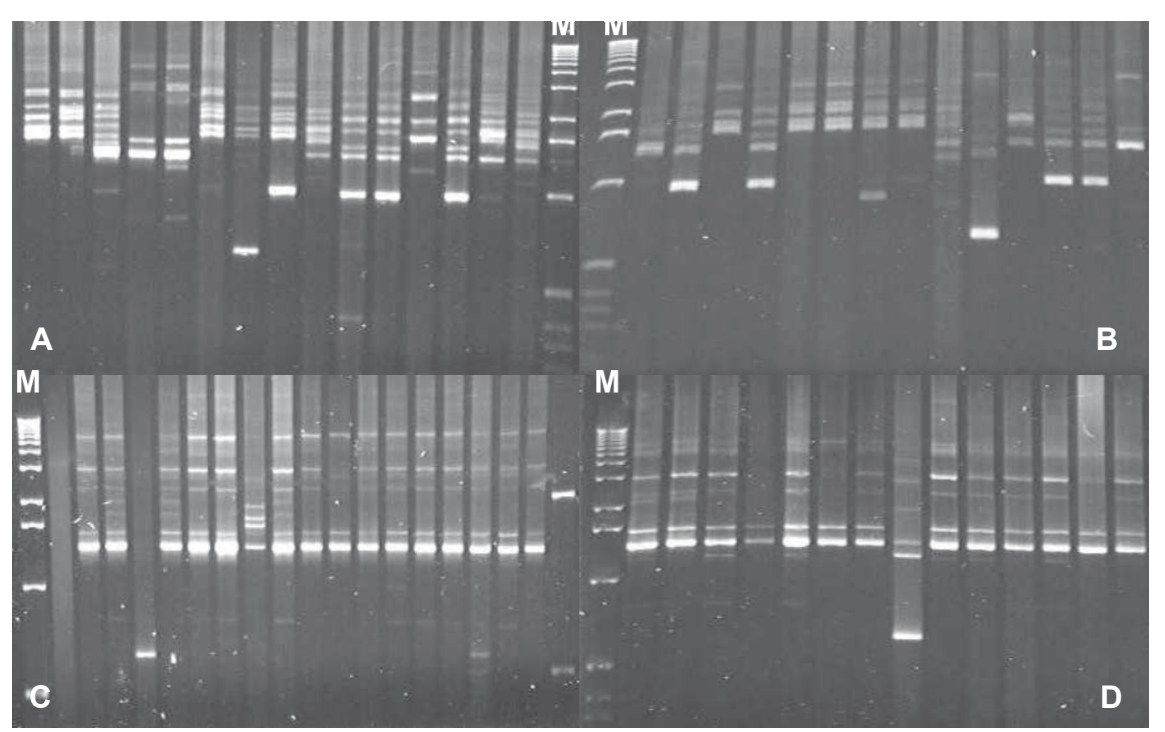

FIGURE 2 - Pot2 rep-PCR analysis showing DNA fingerprinting profiles of Magnaporthe oryzae isolates from cultivars BRS Bonança A. leaves B. Panicle and Primavera C. leaves D. panicle. The DNA molecular size markers are in the lanes labeled M on the left. M1 $=$ Size marker Lambda $1 \mathrm{~kb}$.

TABLE 5 - Genetic diversity of Magnaporthe oryzae population obtained by rep-PCR analysis

\begin{tabular}{cccccc}
\hline \hline Field & $\begin{array}{c}\text { Number of } \\
\text { isolates }\end{array}$ & $\begin{array}{c}\text { Number of } \\
\text { haplotypes }\end{array}$ & $\begin{array}{c}\text { Number of } \\
\text { polymorphic loci }\end{array}$ & $\begin{array}{c}\text { Genotypic } \\
\text { diversity (Nei's) }\end{array}$ & $\begin{array}{c}\text { Standard } \\
\text { deviation(+) }\end{array}$ \\
\hline BF1 & 30 & 26 & 23 & 0.984 & 0.016 \\
BF2 & 38 & 22 & 12 & 0.945 & 0.021 \\
BF3 & 42 & 40 & 17 & 0.998 & 0.006 \\
BF4 & 31 & 6 & 11 & 0.774 & 0.037 \\
BP1 & 20 & 16 & 31 & 0.975 & 0.023 \\
BP2 & 27 & 20 & 21 & 0.960 & 0.025 \\
BP3 & 41 & 32 & 22 & 0.981 & 0.017 \\
BP4 & 37 & 28 & 26 & 0.976 & 0.015 \\
PF1 & 44 & 3 & 8 & 0.089 & 0.059 \\
PF2 & 37 & 3 & 2 & 0.293 & 0.293 \\
PF3 & 36 & 18 & 13 & 0.868 & 0.464 \\
PF4 & 41 & 5 & 29 & 0.476 & 0.085 \\
PP1 & 24 & 14 & 19 & 0.931 & 0.326 \\
PP2 & 23 & 14 & 22 & 0.917 & 0.042 \\
PP3 & 33 & 20 & 20 & 0.943 & 0.027 \\
PP4 & 33 & 19 & 16 & 0.953 & 0.019 \\
\hline
\end{tabular}

The differences in phenotypic diversity of $M$. oryzae populations between cultivars were significant for leaf $(36.62 \%)$ as well as for panicle isolates $(19.07 \%)$, indicating the influence of cultivar in altering the virulence structure of pathogen populations. The influence of cultivar on population structure is difficult to quantify in cultivars with complex genetic basis of resistance, due to the existence of major and minor genes (Yamada \& Lee,
1978). The cultivar BRS Bonança was developed based on multiple cross, involving four parents with possibly different resistance genes, whereas cv. Primavera was developed by simple cross, IRAT 10/LS85-158. The greater diversity of $M$. oryzae population of $\mathrm{cv}$. BRS Bonança than cv. Primavera can be attributed to broad genetic base of the cultivar. These results further showed that the populations of M. oryzae in Brazil could adapt rapidly to newly introduced cultivars. 


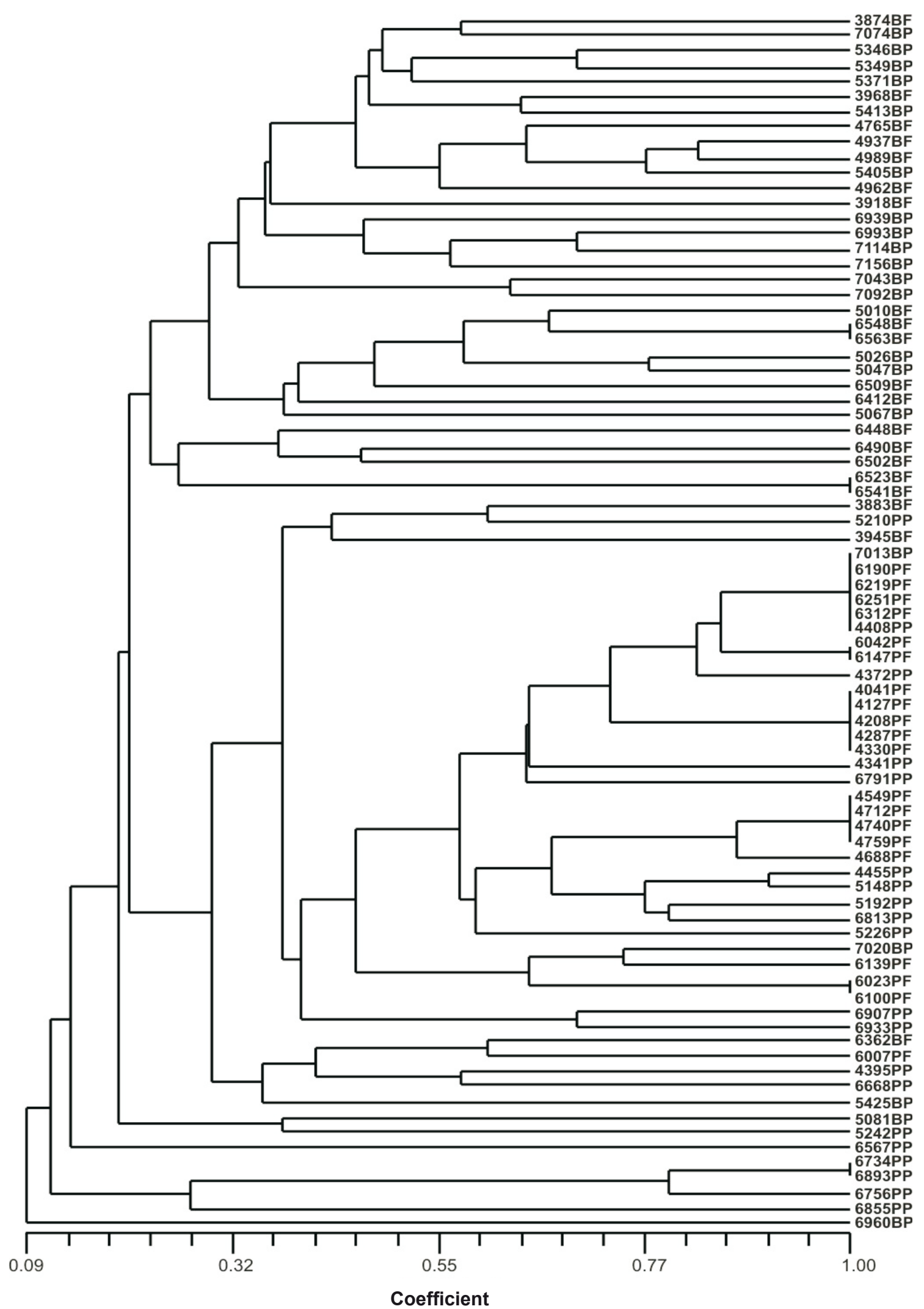

FIGURE 3 - Phenogram of 80 randomly selected isolates of Magnaporthe oryzae from leaves and panicles of rice cultivars BRS Bonança and Primavera, generated by unweighted pair group method arithmetic mean (UPGMA) analysis. Co-phenetic correlation of the phenogram was 0.84. $\mathrm{BF}=\mathrm{BRS}$ Bonança leaf isolates; $\mathrm{BP}=\mathrm{BRS}$ Bonança panicle isolates; $\mathrm{PF}=$ Primavera leaf isolates; $\mathrm{PP}=\mathrm{Primavera}$ panicle isolates. 
The analysis of genetic diversity indicated that $70.38 \%$ and $50.73 \%$, of total diversity was distributed within fields of cvs. BRS Bonança and Primavera, respectively, considering both leaf and panicle isolates. These results agree with the genetic analysis of pathosystem Rhynchosporium secalis barley in Australia. Sixty-six percent of genetic diversity of populations was distributed within the sampling points within the field (McDonald et al., 1999). In the present study, each of the eight fields may be considered as a sampling site. The diversity within a field was greater for panicle isolates than for leaf isolates. On the other hand, the diversity between cultivars was greater for leaf isolates than for panicle isolates. There was no difference in diversity between sub-populations of leaf and panicles. The fungi $M$. oryzae and $R$. secalis are similar in relation to the mode of reproduction, and the perfect stage has still not been found in nature under field conditions.

The molecular genetic analysis (RFLP) of 31 field populations of $R$. secalis collected from 14 countries in five continents revealed that at a global level $58 \%$ of the genetic variation was distributed within fields, while $11 \%$ was distributed among fields within regions, and $31 \%$ among regions (Zaffarano et al., 2006). These results indicated that gene flow is common at the local level.

Low genotypic diversity has been reported for M. oryzae populations from the United States, Europe and the Philippines, where the populations are organized into distinct lineages and there is close association reported between virulence and finger print groups (Chen et al., 1995,; Zeigler et al., 1997). On the other hand, continuous genotypic variation and lack of association between genetic and virulence patterns was observed in other countries (Mekwatanakarn et al., 2000; Park et al., 2003; Rathour et al., 2004). Observations from different countries indicate the possibility of genetic recombination in the pathogen population. There is adequate evidence that the pathogen has the ability to exchange genetic material among isolates. Both mating types and sexually fertile rice isolates have been reported in several countries (Mekwatanakarn et al., 2000; Kumar et al., 1999; Dayakar et al., 2000; Rathour et al., 2004). Isolates of $M$. oryzae yielding abundant ascospores in crosses with different grasses have been reported (Valent \& Chumley, 1994; Kumar et al., 1999). However, the role of perfect stage in nature has not been well defined. The para sexual exchange of DNA has been demonstrated to occur between rice isolates under laboratory conditions, challenging the exclusive clonality of $M$. oryzae populations (Zeigler et al., 1997). Migration from leaf to panicle and recombination may be important factors in shaping the genetic structure of the M. oryzae populations. In general, the diversity in pathogen population was greater within each field and between cultivars rather than between subpopulations of leaf and panicle. The present investigations brought to light the validity of breeding based on tests conducted for leaf blast resistance. However, there is a need for panicle blast resistance testing even though the predominant pathogen population originated from the leaf, because of differences in genetic background.

\section{ACKNOWLEDGEMENTS}

The authors thank Embrapa Research center rice and bean for providing the laboratory and greenhouse facilities for conducting this research and the Coordenação de Aperfeiçoamento de Pessoal de Nível Superior - CAPES for awarding a research fellowship to the first author. Thanks are also due to Pedro Maurício Machado and Romilda Amaral Melo for assistance in the plant pathology laboratory whenever needed.

\section{REFERENCES}

Araújo LG, Prabhu AS, Oliveira CF, Berni RF (2004) Efeito da brusone nas panículas nos componentes de produtividade nas cultivares de arroz Primavera e Bonança. Summa Phytopathologica 30:265-270.

Bonman JM, Estrada BA, Bandong JM (1989) Leaf and neck blast resistance in tropical lowland rice cultivars. Plant Disease 73:388390.

Bonman JM, Khush GS, Nelson RJ (1992) Breeding rice for resistance to pests. Annual Review of Phytopathology 30:507528.

Chen D, Zeigler RS, Leung H, Nelson RJ (1995) Population structure of Pyricularia grisea at two screening sites in the Philippines. Phytopathology 85:1011-1020.

Correa-Victoria FJ, Zeigler RS (1993) Pathogenic variability analysis of Pyricularia grisea at rice blast "hot-spot" breeding site in Eastern Colombia. Plant Disease 77:1029-1035..

Dayakar B, Narayana NN, Gnanamanick SS (2000) Cross compatibility and distribution of mating type alleles of the rice blast fungus Magnaporthe grisea in India. Plant Disease 84:700704.

Doyle JJ, Doyle DJL (1987) A rapid DNA isolation procedure for small quantities of fresh leaf tissue. Phytochemistry Bulletin 19:11-15.

Excoffier L, Smouse P, Quattro J (1992) Analysis of molecular variance inferred from metric distances among DNA haplotypes: application to human mitochondrial DNA restriction data. Genetics 131:479-491.

Filippi MC, Prabhu AS, Araújo LG., Faria JC (2002) Genetic diversity and virulence pattern in field populations of Pyricularia grisea from rice cultivar Metica-1. Pesquisa Agropecuária Brasileira 37:1681-1688.

Filippi MC, Prabhu AS (2001) Phenotypic virulence analysis of Pyricularia grisea isolates from Brazilian upland rice cultivars. Pesquisa Agropecuária Brasileira 36: 27-35.

George MLC, Nelson RJ, Zeigler RS, Leung H (1998) Rapid population analysis of Magnaporthe grisea by using rep-PCR and 
endogenous repetitive DNA sequence. Phytopathology 88:223228.

Hamer JE (1991) Molecular probes for rice blast disease. Science $52: 632-633$.

Han SS, Ra DS, Choi SH., Kim CK (1997) Populations dynamics of Pyricularia grisea during leaf and panicle blast stages in the same field. Korean Journal Plant Pathology 13:408-415.

International Rice Research Institute (1988) Standard evaluation system for rice. $3^{\text {rd }}$ ed. Los Baños. International Rice Research Institute.

Kang S, Lee Y (2000) Population structure and race variation of the rice blast fungus. Plant Pathology Journal 16:1-8.

Kumar J, Nelson RJ, Zeigler RS (1999) Population structure and dynamics of Magnaporthe grisea in the Indian Himalayas. Genetics 152:971-984.

McDonald BA, Linde C (2002) The population genetics of plant pathogens and breeding strategies for durable resistance. Euphytica 124:163-180.

Mekwatanakarn P, Kositratana W, Levy M, Zeigler RS (2000) Pathotype and avirulence gene diversity of Pyricularia grisea in Thailand as determined by rice lines near-isogenic for major resistance genes. Plant Disease 84:60-70.

Nei M (1987) Molecular evolutionary genetics. New York NY. Columbia University Press.

Park SY, Milgroom MG, Han SS, Kang S, Lee YH (2003) Diversity of pathotypes and DNA fingerprint haplotypes in population of Magnaporthe grisea in Korea over two decades. Phytopathology 93:1378-1385.
Prabhu AS, Castro EM, Araujo LG, Berni RF (2003) Resistance spectra of six elite breeding lines of upland rice to Pyricularia grisea. Pesquisa Agropecuária Brasileira 38:203-210.

Prabhu AS, Filippi MC, Araujo LG (2002) Pathotype diversity of Pyricularia grisea from improved upland rice cultivars in experimental plots. Fitopatologia Brasileira 27:468-473.

Ra DS, Oh JH, Han. SS, Kim CK (1995) Temporal and spacial blast incidence in new cultivars and elite lines of rice in Korea (III). Korean Journal Plant Pathology 11:338-343.

Rathour R, Singh BM, Sharma TR, Chauhan RS (2004) Population structure of Magnaporthe grisea from North-western Himalayas and its implications for blast resistance breeding of rice. Journal of Phytopathology 52:3004-312.

Teng. PS (1994) The epidemiological basis for blast management. In: Zeigler RS, Leong SA, Teng PS (Eds.) Rice blast disease. Wallingford. CAB International. pp. 409-433.

Valent B, Chumley FG (1994) Avirulence genes and mechanisms of genetic instability in the rice blast fungus. In: Zeigler RS, Leong SA, Teng PS,(Eds.) Rice blast disease. Wallingford. CAB International. pp. 111-134.

Yamada M, Lee EJ (1978) Breakdown of Tongil-lines cause of Pyricularia oryzae in Korea. Plant Protection 32:238-242

Zaffarano PL, Mcdonald BA, Zala M, Linde CC (2006) Global hierarchical gene diversity analysis suggests the Fertile Crescent is not the center of origin of the barley scald pathogen Rhynchosporium secalis. Phytopathology 96:941-950.

Zeigler RS, Scott RP, Leung H, Bordeos AA, Kumar J (1997) Evidence of parassexual exchange of DNA in rice blast fungus challenges its clonality. Phytopatology 87:248-287. 